\title{
Low Temperature VOC Combustion Over Manganese, Cobalt and Zinc Alpo Molecular Sieves $_{4}$
}

\author{
Semi-Annual Report \\ October 1, 1996 - March 31, 1997 \\ By

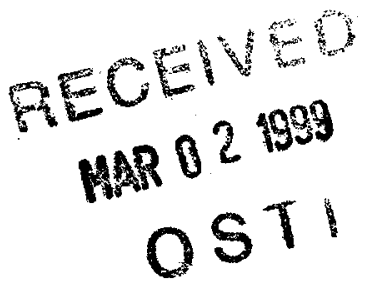 \\ Rosemarie Szostak
}

Work Performed Under Contract No.: DE-FG22-95PC95218

For

U.S. Department of Energy

Office of Fossil Energy

Federal Energy Technology Center

P.O. Box 880

Morgantown, West Virginia 26507-0880

By

Clark Atlanta University

223 James P. Brawley Drive

Atlanta, Georgia 30314 


\section{Disclaimer}

This report was prepared as an account of work sponsored by an agency of the United States Government. Neither the United States Government nor any agency thereof, nor any of their employees, makes any warranty, express or implied, or assumes any legal liability or responsibility for the accuracy, completeness, or usefulness of any information, apparatus, product, or process disclosed, or represents that its use would not infringe privately owed rights. Reference herein to any specific commercial product, process, or service by trade name, trademark, manufacturer, or otherwise does not necessarily constitute or imply its endorsement, recommendation, or favoring by the United States Government or any agency thereof. The views and opinions of authors expressed herein do not necessarily state or reflect those of the United States Government or any agency thereof. 


\section{DISCLAIMER}

Portions of this document may be illegible in electronic image products. Images are produced from the best available original document. 


\subsection{Introduction}

The objective of this project is to prepare manganese, cobalt and zinc containing $\mathrm{AlPO}_{4} \mathrm{molecular}$ sieves and evaluate their catalytic activities for the removal of low levels of volatile organic compounds (VOCs) from gas streams. This report highlights our research activities for period October 1,1996 to March 31, 1997.

\subsection{Experimental Procedure}

\section{Preparation and characterization of catalysts}

Procedures for the catalysts preparation and their characterization by X-ray Diffraction (XRD) and Diffuse Reflectance Infrared Spectroscopy (DRIFTS) were outlined in Semi-Annual Report \#1 (period August 1, 1995 to February 31, 1996).

\section{Conversion of methylene chloride in a fixed bed continuous flow reactor}

The design and construction of the fixed bed upflow microreactor used in the following catalytic studies was reported in Semi Annual Report \# 2 (March 1,1996 to August 31, 1996). The procedure for a typical catalytic run was as follows: A $0.50 \mathrm{~g}$ sample of catalyst was placed on the frit inside the reactor tube and was kept in place by a small plug of glass wool. The reactor tube was heated to the desired reaction temperature. Air was bubbled at flow rate of $1 \mathrm{cc} / \mathrm{min}$ through methylene chloride contained in a $200 \mathrm{~mL}$ Dreshel bottle which was ice cooled to $0^{\circ} \mathrm{C}$. The methylene chloride saturated stream of air was made up with an additional $15 \mathrm{~mL} / \mathrm{min}$ of air to give a combined flow rate of $16 \mathrm{~mL} / \mathrm{min}$ of gas going through the catalyst bed at space velocity of approximately $(1920 \mathrm{~mL}$ gas $/ \mathrm{mLcatalyst} / \mathrm{hr}) .250 \mu \mathrm{L}$ sample of the reactor effluent was injected into the gas chromatograph (GC) at regular intervals using the Valco six port valve gas sample loop. The operating conditions for the $\mathrm{GC}$ were as follows: Injector port temperature $200^{\circ} \mathrm{C}, \mathrm{FID}$ Detector temperature $200^{\circ} \mathrm{C}$, and oven temperature isothermal at $100^{\circ} \mathrm{C}$. Separation was done using an Altech stainless steel packed column of dimensions $6 \mathrm{ft} \times 1 / 8$ inch, containing Porapak $\mathrm{Q}$ stationery phase. The retention time (RT) of methylene chloride under these conditions was 8.87 minutes.

\section{Studies on methylene chloride using DRIFTS}

While we awaited the modification of the reactor to characterize and quantify the reaction products, DRIFTS was used to give some insight into the possible nature of these products. The adsorption and oxidation of methylene were performed in the DRIFT cell over both CoAPO-36 (sample D) and CoY. The catalysts powder was placed on a $\mathrm{KBr}$ bed inside the reaction cell which was then evacuated to $10^{-5}$ torr while heating to $400^{\circ} \mathrm{C}$ for a minimum of $12 \mathrm{hrs}$. After cooling the cell to $300^{\circ} \mathrm{C}$, the catalyst was allowed to interact with 15 torr of methylene chloride 
vapor for $1 \mathrm{hr}$. The cell was then evacuated at $10^{-5}$ torr for $1 \mathrm{~h}$ to remove physisorbed methylene chloride. Spectra were recorded (1000 scans) and ratioed against the pure activated molecular sieve to observe the interaction of chemisorbed methylene chloride with the catalyst surface.

Oxidation of the chemisorbed methylene chloride was conducted as follows: 100 torr of dry oxygen was allowed to interact with the chemisorbed methylene chloride at $300^{\circ} \mathrm{C}$ under static conditions. The transformation of the surface products was observed over time. The spectrum of chemisorbed methylene chloride was used as a background to obtained the spectra of the oxidized species.

\section{Results and Discussion}

The results from the reactor runs for the oxidation of methylene chloride using various molecular sieves are tabulated in Table 2 . Though all catalysts, with the exception of TS1 and CoY were synthesized from reaction mixtures of similar molar composition ratios, wide variation in their catalytic activities were observed. CoAPO-36 showed catalytic activity closest to the reference catalyst, CoY, which showed highest methylene chloride conversion. The $\mathrm{Ti}, \mathrm{Mn}, \mathrm{Mg}$ and $\mathrm{Zn}$ containing molecular sieves all showed low catalytic activities at $400^{\circ} \mathrm{C}$. Further experiments was therefore focused on Co containing samples.

Figure 1 shows the catalytic activity of CoAPO-36 as a function of temperature and cobalt content of the catalysts. Methylene chloride conversion showed distinct temperature dependency. Exponential increase in conversion levels was observed in the temperature range from $250^{\circ} \mathrm{C}$ to $400^{\circ} \mathrm{C}$, reaching $100 \%$ conversion at the higher temperature. Chatterjee and Greene reported similar results using zeolite $\mathrm{Y}$ exchanged with $\mathrm{H}, \mathrm{Ce}$ and $\mathrm{Cr}^{1}$ Catalytic activity increased with $\mathrm{Co}$ content until approximately $4.8 \mathrm{wt} \% \mathrm{Co}$. No further increase in activity was observed for samples with higher Co content. CoY consistently showed higher conversion than CoAPO-36, though the former contained a lower Co content $(2.5 \mathrm{Wt} . \%)$. This may be a result of the higher concentration of Bronsted acid sites that is available in its structure in comparison with CoAPO36 , as was revealed by DRIFTS.

With regards to stability of the catalysts under reaction conditions, CoAPO-36 samples maintained high crystallinity as was indicated by XRD. Peak positions ( $2 \theta$ values) and peaks heights in the $\mathrm{X}$-ray diffractograms remained unchanged from a comparison of the calcined catalysts before and after catalytic runs.

The promising activity shown by the Co containing molecular sieves prompted us to investigate the activity of other Co containing topologies from the aluminophosphate family. Thus large pore CoAPO-5 (pore dimension of $0.73 \mathrm{~nm}$ ) and medium pore CoAPO-11 (pore dimensions $0.63 \mathrm{~nm}$ $\mathrm{x} 0.39 \mathrm{~nm}$ ) were investigated and compared with large pore CoAPO-36 (pore dimension of 0.65 $\mathrm{nm} \times 0.75 \mathrm{~nm})^{2}{ }^{2}$ Here again CoAPO-36 shows highest catalytic activity among the three. Though CoAPO-36 and CoAPO-5 are both large pore materials, it is known that the former container stronger Bronsted acid sites was demonstrated in its n-butane cracking activity. ${ }^{3}$ Since acid sites seems to play an important role in methylene chloride oxidation, this may explain why CoAPO-36 
show greater catalytic activity. In the case of CoAPO-11 which is also know to possess strong Bronsted acid sites, its lower catalytic activity may be related to its smaller pore dimensions causing slow diffusion of methylene chloride into its pores.

Efforts are ongoing to improve the reactor so that products can be analyzed proper mass balance can be conducted. In the meantime, qualitative analysis for the presence of $\mathrm{HCl}$ as a reaction product was assessed as a function of temperature by passing the reactor effluent through $20 \mathrm{~mL}$ of deionized water for 10 minutes using CoAPO-36 (D). The change in $\mathrm{pH}$ was monitored using a $\mathrm{pH}$ meter and the increase in $\mathrm{H}_{3} \mathrm{O}^{+}$concentration was determined as a function of temperature. A direct correlation was observed between methylene chloride conversion and $\mathrm{HCl}$ (Figure 3).

Figures 4 and 5 show the spectra of CoAPO-36 (D) at $300^{\circ} \mathrm{C}$ before and after methylene chloride was chemisorbed respectively. The negative peaks observed at $3672 \mathrm{~cm}^{-1}$ and $3589 \mathrm{~cm}^{-1}$ after the adsorption of methylene chloride are due to the interaction of the VOC with the hydroxyls on the catalyst surface. Figure 6 shows results from oxidation of chemisorbed methylene in air at $300^{\circ} \mathrm{C}$. The hydroxyl band at $3666 \mathrm{~cm}^{-1}$ gradually reappears as the time of oxidation was increased, suggesting the gradual oxidation of the VOC and an important role played by these acidic centers. The spent catalyst was observed to undergo a color change from yellow green to blue and this is attributed to a change in the oxidation state of the cobalt from $3^{+}$to $2^{+}$. The above suggests that the VOC is simultaneously interacting with both the acid site and the Co center.

Among the main reaction products expected from this reaction are $\mathrm{CO}_{2}$ and $\mathrm{CO}$. The double bands appearing at $2363 \mathrm{~cm}^{-1}$ and $2326 \mathrm{~cm}^{-1}$ in Figure 7 is assigned to $\mathrm{CO}_{2}{ }^{4}$ The intensities of these bands and therefore the amount of $\mathrm{CO}_{2}$ produced increased with oxidation time up 60 minutes. The band at 2170 is assigned to $\mathrm{CO}$ and its intensity did not appear to increase with oxidation time (Spectra 1-4). In Figure 8 bands at $1788 \mathrm{~cm}^{-1}$ and $1735 \mathrm{~cm}^{-1}$ corresponds to the $\mathrm{C}=\mathrm{O}$ stretching and $\mathrm{CCl}_{2}$ assymetric stretching respectively in accordance with published work. The intensities of both peaks increased with increase in the time of oxidation, and could possibly be due to the formation of phosgene on the surface of the catalysts.

In these studies both $\mathrm{CO}$ and $\mathrm{CO}_{2}$ were identified in the reaction products along with some intermediates which were tentatively identified.

\subsection{Summary and Future work}

A range of molecular sieves were screened for their catalytic activities in the destruction of the chlorinated VOC, (methylene chloride). CoAPO-36 showed best catalytic activity for the process and compared well with CoY. Catalytic activity increased with cobalt content up to $4.8 \mathrm{wt} . \%$. The Ti containing zeolite TS1, as well as the $\mathrm{Mg}$, Co and $\mathrm{Zn}$ containing MeAPOs showed much lower activities compared with CoAPO-36.

Future work will focus on further qualitative and quantitative analysis of reaction products so that trends in selectivity towards $\mathrm{CO}$ and $\mathrm{CO}_{2}$ can be assessed by DRIFTS and gas chromatography. MeAPOs will also be screened for their activities in the decomposition of other other VOCs such as carbon tetrachloride. 


\subsection{Presentation of results}

Preliminary results from this project were presented by undergraduate student Miss Keera Cleare at the Fifth Annual Historical Black College and Universities and Other Minority Institution/ Private Sector Energy Research and Development Technology Transfer Symposium in Baton Rouge Louisiana; March 2-4, 1997, for which she placed first in a poster competition.

Table 1: Synthesis gel compositions and wt. \% $\mathrm{Co}$ and $\mathrm{Al}$ in products of CoAPO-36 samples.

\begin{tabular}{|c|c|c|}
\hline \multirow[t]{2}{*}{$\begin{array}{l}\text { ** Molar composition of reaction } \\
\text { mixtures }\end{array}$} & \multicolumn{2}{|c|}{$\frac{* \text { Wt } \% \text { composition }}{\text { by chemical analysis }}$} \\
\hline & $\% \mathrm{Co}$ & $\% \mathrm{Al}$ \\
\hline & 2.5 & 25.0 \\
\hline & 4.8 & 23.5 \\
\hline & 6.5 & 24.4 \\
\hline & 5.0 & 22.1 \\
\hline & & 20.1 \\
\hline & 2.5 & nd \\
\hline
\end{tabular}

Table 2: Catalytic activities of various molecular sieves for methylene chloride oxidation

\begin{tabular}{|l|c|l|l|}
\hline Catalysts & \multicolumn{3}{|c|}{ Conversion (\%) } \\
& $300^{\circ} \mathrm{C}$ & $350^{\circ} \mathrm{C}$ & $400^{\circ} \mathrm{C}$ \\
\hline CoY & 45.4 & 93.6 & 97.5 \\
CoAPO-36 (B) & 37.1 & 77.6 & 100 \\
MnAPO-36 & 7.5 & 16.4 & 37.2 \\
MAPO-36 & 7.8 & 12.3 & 19.8 \\
ZnAPO-36 & 3.9 & 4.1 & 12.7 \\
TS1 & 2.1 & 11.6 & 14.6 \\
\hline Homogeneous run & 0 & & 14.1 \\
\hline
\end{tabular}




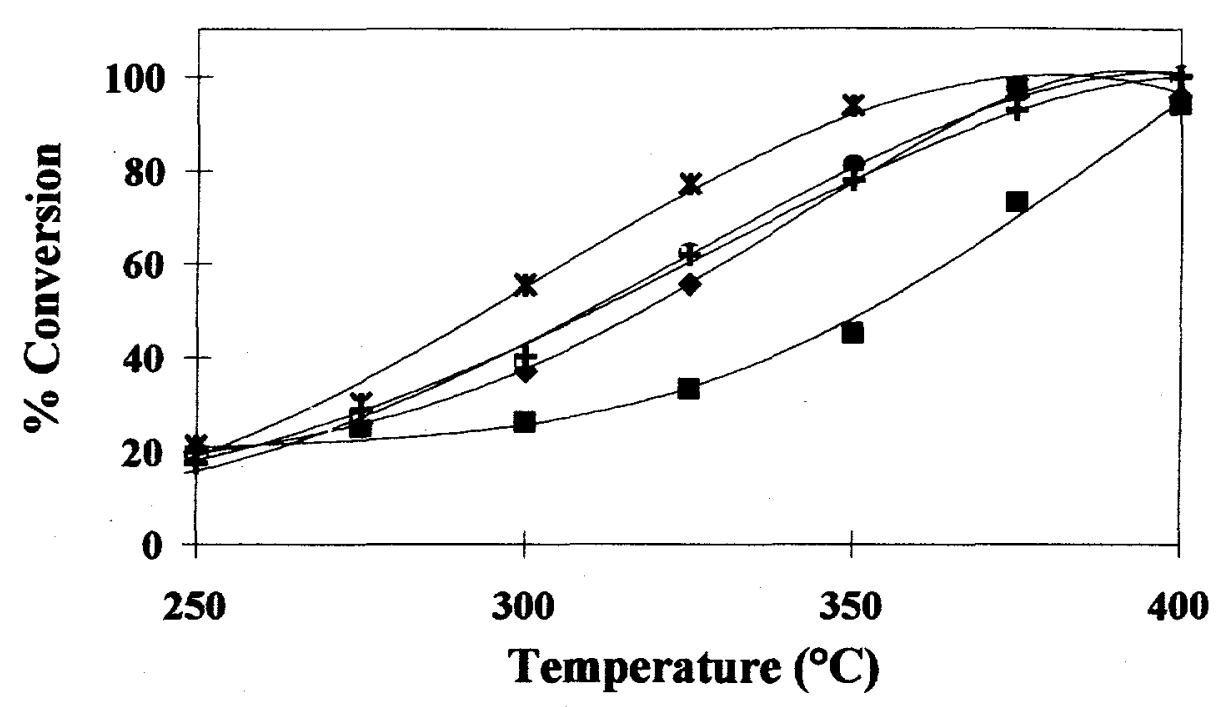

$\begin{aligned} & -\mathrm{A}=2.5 \text { wt. } \% \quad \bullet \mathrm{B}=4.8 \mathrm{Wt} \% \\ & \times \mathrm{CoY}=2.5 \mathrm{Wt} \%+\mathrm{E}=10.8 \mathrm{Wt} \%\end{aligned} \rightarrow \mathrm{C}=6.5 \mathrm{Wt} \% \%$

Figure 1: Methylene chloride conversion vs. reaction temperature and Co content of CoAPO-36.

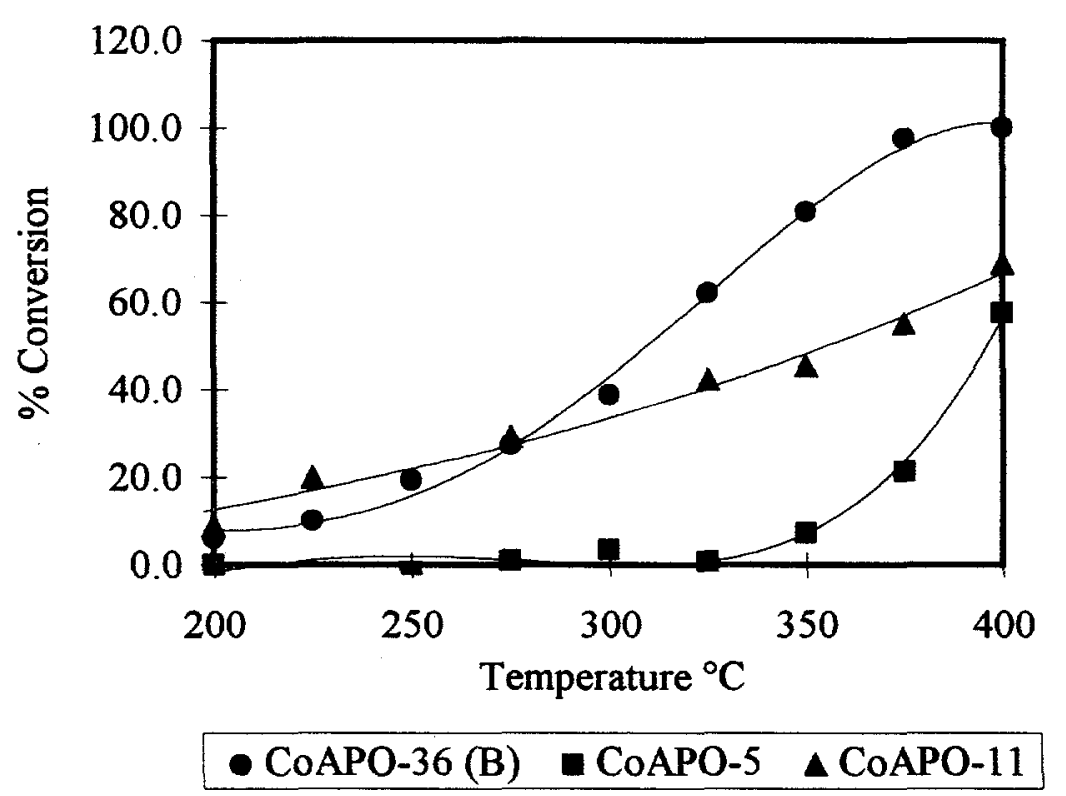

Figure 2: Conversion of methylene chloride on Co containing MeAPOs of various topologies. 


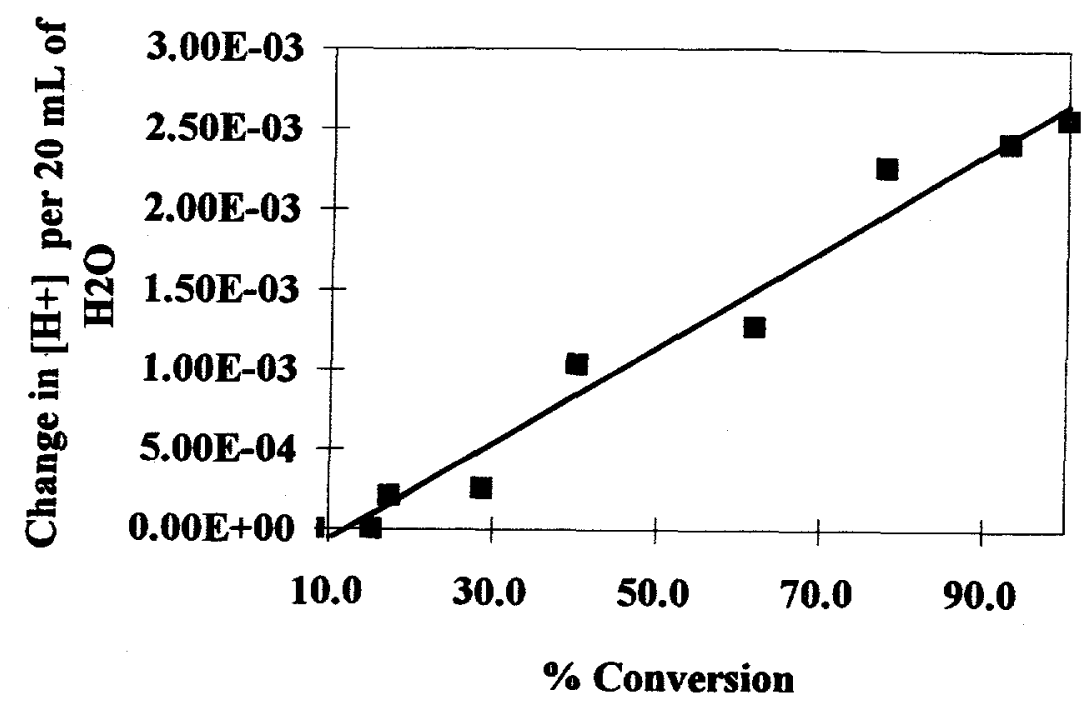

Figure 3: $\mathrm{HCl}$ production vs. methylene chloride conversion on CoAPO-36 (B)

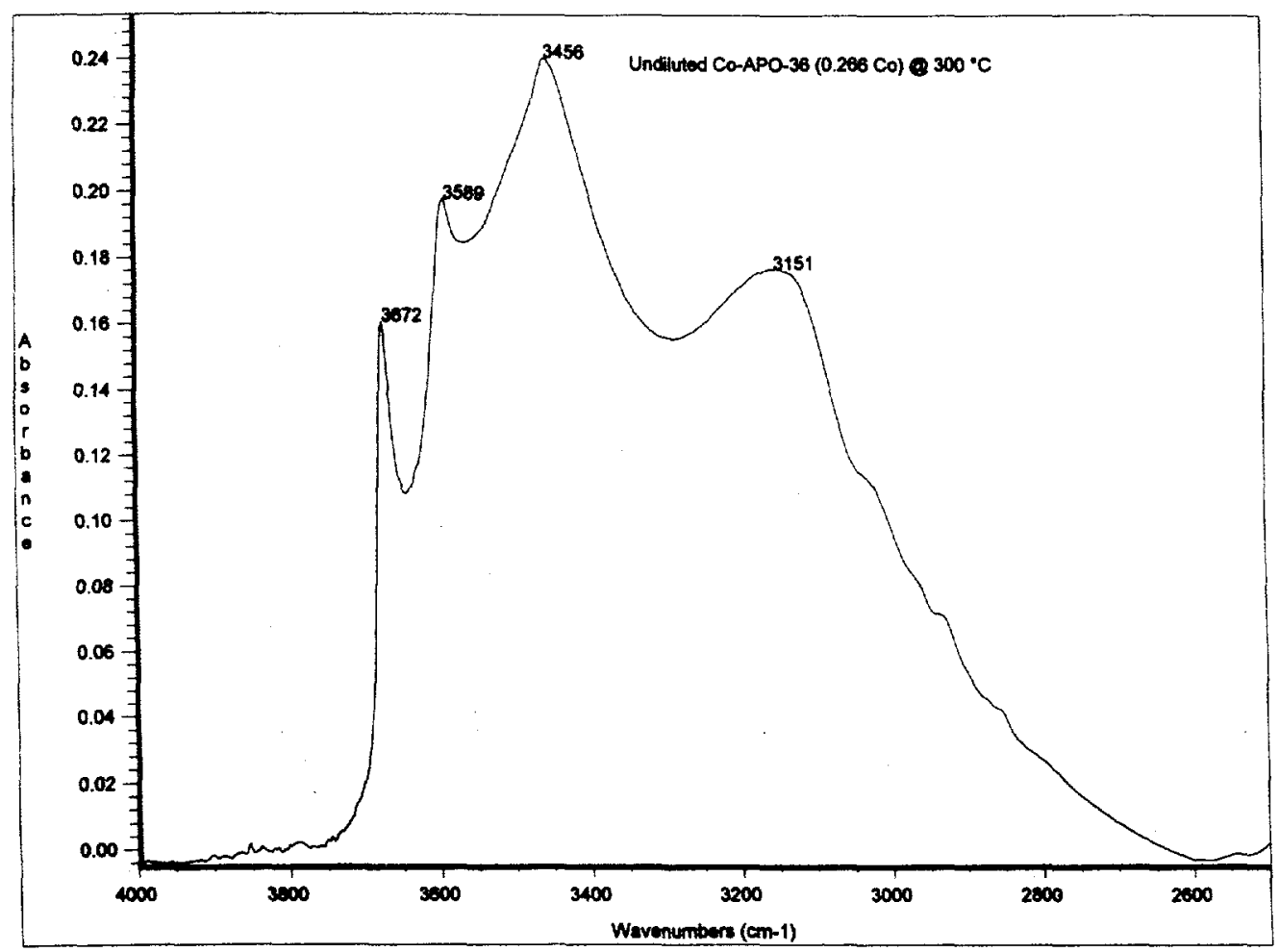

Figure 4. IR Spectrum showing OH region of CoAPO-36 (D) after heating and evacuation. 


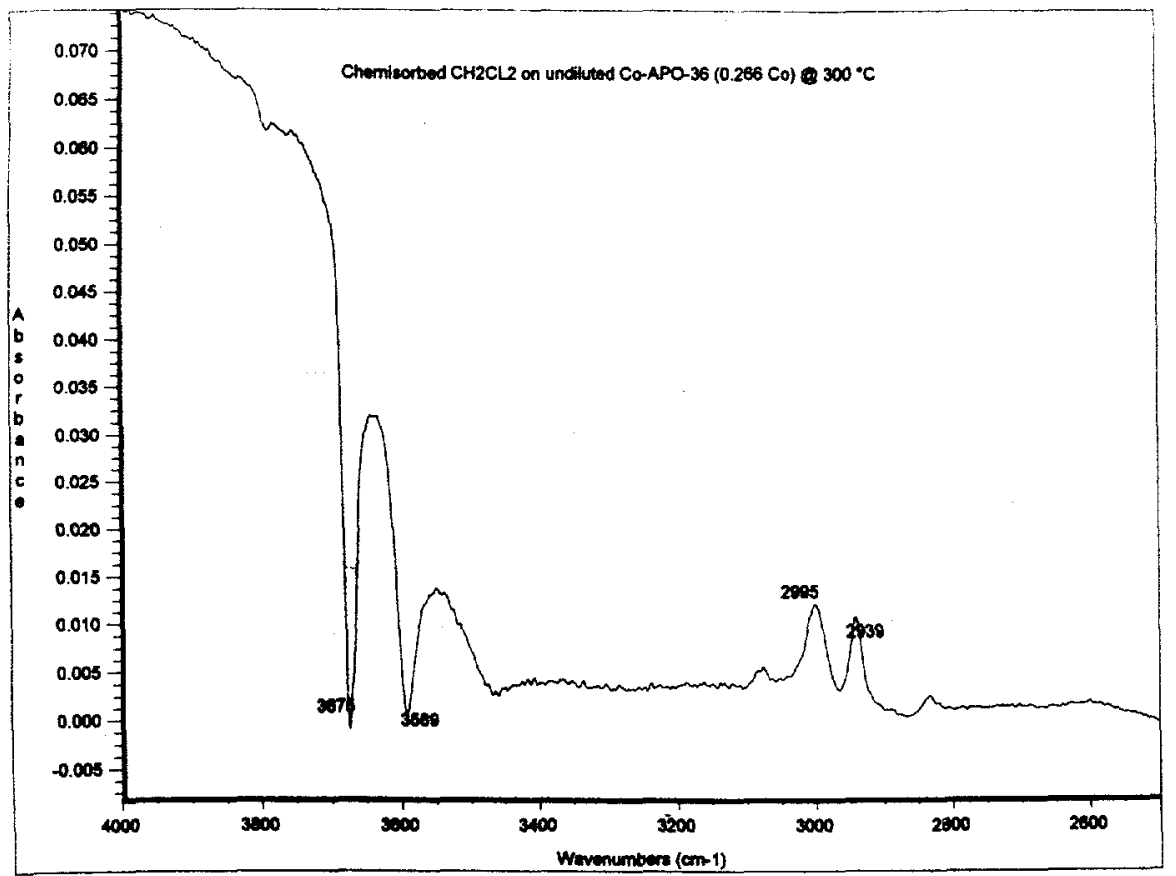

Figure 5: IR Spectrum showing OH region of CoAPO-36 (D) after methylene chloride was chemisnrhed at $300^{\circ} \mathrm{C}$.

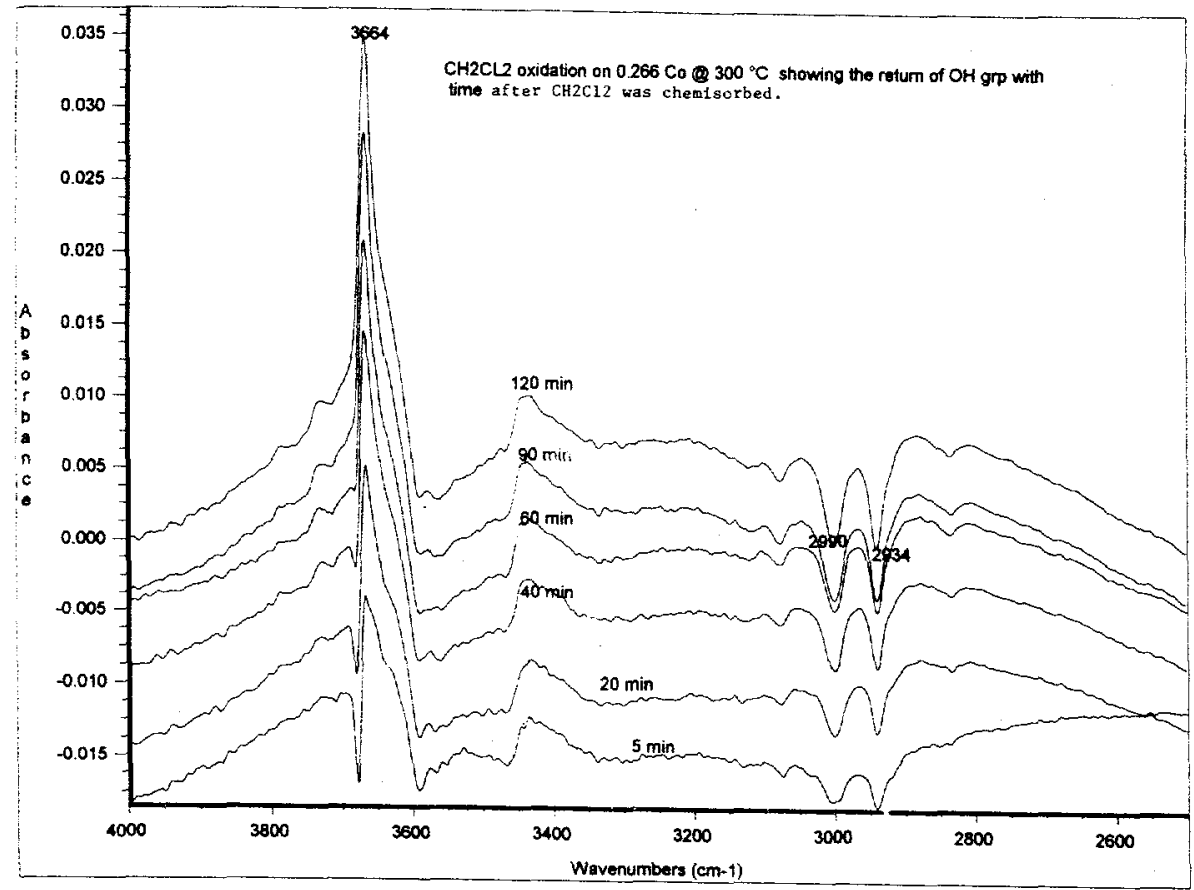

Figure 6. IR spectra of CoAPO-36 (D) showing the return of $\mathrm{OH}$ groups with time during the oxidation of chemisorbed methylene chloride. 


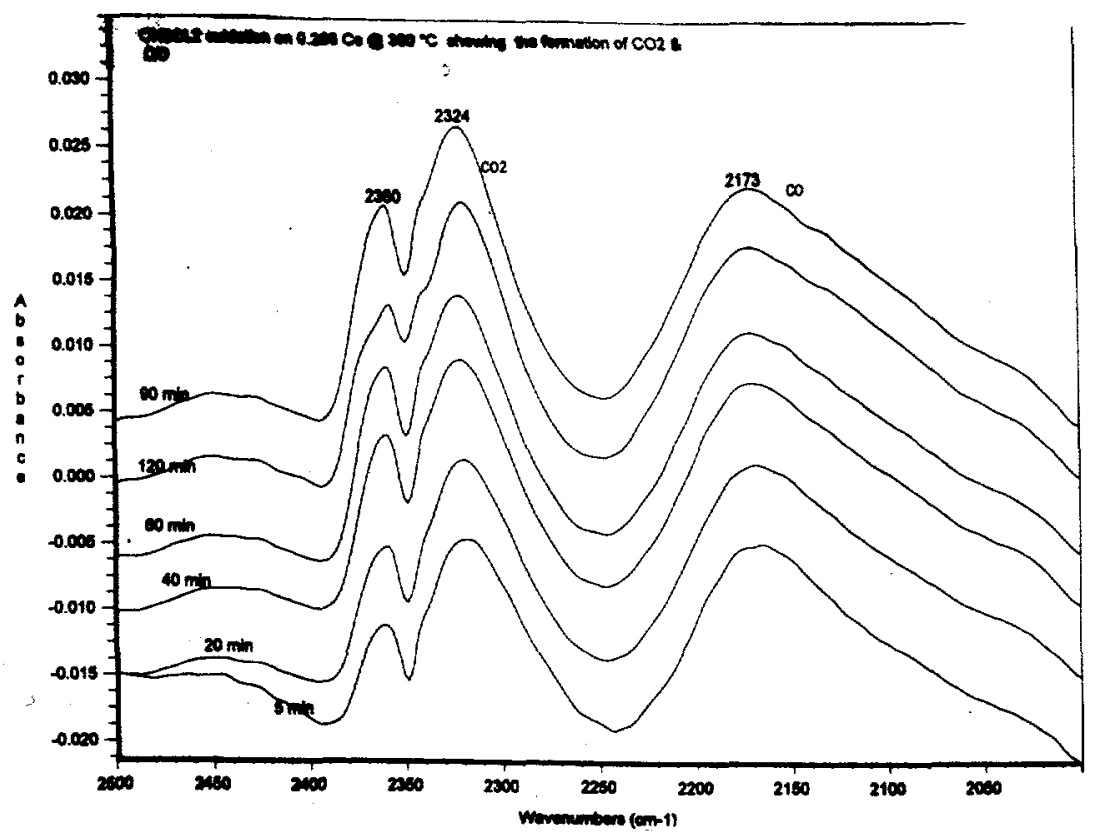

Figure 7. IR spectra of CoAPO-36 (D) showing the formation of $\mathrm{CO}$ and $\mathrm{CO}_{2}$ with time during the oxidation of chemisorbed methylene chloride.

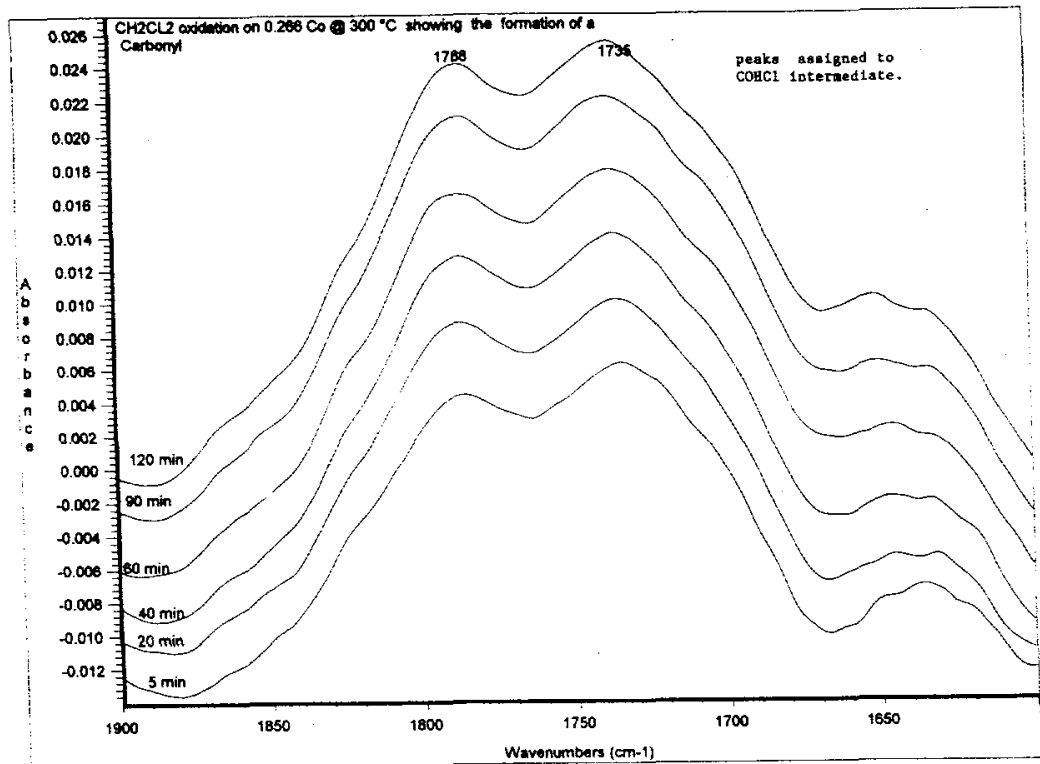

Figure 8. IR spectra of CoAPO-36 (D) showing the formation of carbonyl species (possibly $\mathrm{COHCl}$ intermediate) with time during the oxidation of chemisorbed methylene chloride. 


\section{References}

${ }^{1}$ Chateriee, S., Greene, H., Appl. Catal. A: General 98 (1993)139-158.

2 Meier, W. M., Olson, D. H., Atlas of zeolite structure types 3rd ed., Butterworth-Heinemann, MA (1992)

${ }^{3}$ Nakashiro, K., Y. Ono, J. Chem. Soc. Faraday Trans. 1, 8719 (1991).

${ }^{4}$ Ramachandran, B., Greene, H., Chatterjee, S., Appl. Catal. B., Environmental 8 (1996)157-182 